\title{
Physico-chemical investigation of variously extracted medicinally useful materials from the rhizomes of Alpinia calcarata Rosc. of Kumaun Region, India
}

\author{
Durvesh K Tyagi $^{1 \bowtie}$ and Nikhil Kumar ${ }^{2}$
}

Received: 05.01.2013

Accepted: 27.03.2013

\begin{abstract}
Extractions of medicinally useful materials from the rhizome of Alpinia calcarata Rosc. separately through solvents of decreasing polarities, viz., water, ethanol, diethyl ether and petroleum ether are also carried out. In the rhizome of $A$. calcarata the water extract has maximum yield.Odours vary in differently extracted materials. Diethyl ether and petroleum ether extracted materials show a sufficientdegree of unsaturation. All of the solvent extracted materials are dextro rotatory. Specific gravities, refractive indices, acid, saponification and iodine values of these variously extracted materials are also reported. Tests for the presence of specific natural products indicate the presence of steroids and flavonoids in most of the materials. Some of them possess carbohydrates also.
\end{abstract}

\section{Keywords: Alpinia calcarata, Zingiberaceae, medicinal plants}

\section{Introduction}

The plant Alpinia calcarata Rosc., (Syn. Alpinia bracteata Rosc., Renealmia calcarata Haw) also belongs to Zingiberacea family. It is called Toroni in Oriya and Kattchenuin Malyalam (Pullaiah, 2006). A. calcarata Rosc. is a slender, rhizomatous herb, 60$120 \mathrm{~cm}$ in height, often cultivated in gardens in eastern and southern India for its white flowers (The Wealth of India, 1985) Recently the efficacy of essential oil ofthe plant and its majorconstituent, 1,8cineole, as protectants of cowpea against Callosobruchusmaculatus has been reported (Abeywickrama, 2006)Presence of two bislabdanicditerpenoids from the rhizomes has been reported by Kong et al.(2004)in a Chinese sample.Looking to the variety of uses, a detailed study of physico-chemical properties of the various solvent extracted materials and essential oils from the rhizomes of these plants andetermination of natural product groups seem to be important.

\section{Material and Methods}

Authenticated rhizomes of Alpinia calcarata were procured from Pantnagar and authenticity verified

\footnotetext{
Author's Address

${ }^{1}$ S.P.R.C. P.G. College Rohalki Kishanpur, Haridwar

E-mail : dhruvtyagi83@gmail.com

${ }^{2}$ Department of Applied Chemistry, B. S. M College of Engineering, Roorkee
}

from F.R.I. Dehradun. Specimens have been deposited in the herbarium of Plant Medicine Section of the Chemistry Department of the University under the registry no. 19/15and available for inspection. The procured rhizomes were washed with luke warm water and dried in shade.

\section{Extraction through solvents \\ Extraction through water}

$100 \mathrm{~g}$ of the crushed rhizome were boiled with doubly distilled water for $1 \mathrm{~h}$. The extract was filtered and water was evaporated.15.4 $\mathrm{g}$ dark brown solid materials was obtained from $A$. calcarata.

\section{Extraction through ethanol}

$100 \mathrm{~g}$ crushed material was kept in a sufficient quantity of ethanol in a Soxhlet extractor for $72 \mathrm{~h}$. Dark brown decoctions in case of $\boldsymbol{A}$. calcarata wascollected.A fresh quantity of ethanol was added again to the same material and kept for another 72 h. Process was repeated till the extract became colourless. All the extracted solutions of a plant material were mixed and ethanol separated by vacuum distillation. $5.25 \mathrm{~g}$ dark brownsolidwas obtained. 
Extraction through diethyl ether

Similar procedure, as for ethanol, was carried out. $3.56 \mathrm{~g}$ yellowish brown viscous oil was obtained.

\section{Extraction through petroleum ether}

Similar procedure, as for ethanol, was carried out. $1.68 \mathrm{~g}$ yellowish light brown viscous oil was obtained.

\section{Study of Properties}

The specific gravity, refractive index, $\mathrm{pH}$ and optical rotation were determined and presence of various possible families of natural product compounds were tested. Acid, saponification and iodine values were determined for essential oil, and also for the various extracted materials using.

Table 1: Results of the analysis of materials obtained by extractions through solvents of different polarities

\begin{tabular}{|c|c|c|c|c|}
\hline \multirow{2}{*}{ Properties } & \multicolumn{4}{|c|}{ Material extracted through } \\
\cline { 2 - 5 } & Petroleum ether & Diethyl ether & Ethanol & Water \\
\hline Colour of decoction & Yellow & Yellow & Dark brown & Dark red \\
\hline Colour of extracts & $\begin{array}{c}\text { Yellowish light } \\
\text { brown }\end{array}$ & Yellowish brown & Dark brown & Dark brown \\
\hline State & Viscous oil & Viscous oil & Solid & Solid \\
\hline Odour & Spicy & Sweet & Spicy & Sharp spicy \\
\hline Yield $(\%, w / w)$ & 1.68 & 3.56 & 5.25 & 15.40 \\
\hline pH & 5.60 & 6.60 & 4.80 & 5.70 \\
\hline $\begin{array}{c}\text { Refractive index } \\
(0.025 \% \text { solution })\end{array}$ & 1.34 & 1.33 & 1.36 & 1.33 \\
\hline Specific gravity $\left(30^{\circ} / 30^{\circ}\right)$ & 0.8662 & 0.8937 & - & - \\
\hline $\begin{array}{c}\text { Optical rotation }\left(25^{\circ} \mathrm{C}\right) \\
(0.025 \% \text { solution })\end{array}$ & $38^{\circ}$ & $2 \% 36^{\prime}$ & $42^{\prime}$ & $4^{\circ} 05^{\prime}$ \\
\hline Acid value & 35.62 & 31.37 & 35.37 & 19.24 \\
\hline Saponification value & 168.6 & 164.2 & 182.2 & 83.26 \\
\hline Iodine value & 63.32 & 52.61 & 15.49 & 16.36 \\
\hline
\end{tabular}

Table 2: Results of the analysis of the extracted materials for different specific natural products

\begin{tabular}{|l|l|l|l|l|}
\hline Specific natural products & & & & \\
\hline & Petroleumether & Diethylether & Ethanol & Water \\
\hline Carbohydrates & & & & \\
\hline Molisch test Alkaloids & $-\mathrm{ve}$ & $-\mathrm{ve}$ & $+\mathrm{ve}$ & $+\mathrm{ve}$ \\
\hline Mayer's test Steroids & $-\mathrm{ve}$ & $-\mathrm{ve}$ & $-\mathrm{ve}$ & -ve \\
\hline $\begin{array}{l}\text { Salkowski reaction } \\
\text { Carotenoids }\end{array}$ & $+\mathrm{ve}$ & $+\mathrm{ve}$ & $+\mathrm{ve}$ & -ve \\
\hline Sulphuric acid test & $-\mathrm{ve}$ & & & \\
\hline Flavonoids Proteins & $-\mathrm{ve}$ & $-\mathrm{ve}$ & $-\mathrm{ve}$ & $-\mathrm{ve}$ \\
\hline Xanthoproteic test & $-\mathrm{ve}$ & $-\mathrm{ve}$ & $+\mathrm{ve}$ & $-\mathrm{ve}$ \\
\hline Biuret test & $-\mathrm{ve}$ & $-\mathrm{ve}$ & $-\mathrm{ve}$ & $-\mathrm{ve}$ \\
\hline
\end{tabular}


the methods described by Garratt (1964), Guenther (1963) and in monographs of I.S.I. (1984). The presence of various possible specific natural products alkaloids, proteins, flavonoids, carbohydrates and carotenoids were tested by usual methods.

\section{Results and Discussion}

Yields and physico-chemical properties of extracted materials are described in Table 1, while the results of the presence of specific natural products are summarized in Table 2. Also, all the three oils give positive tests for the presence of aldehydic, ketonic, alcoholic and ester groups.High yield of the material in A. calcarata water extract indicates a high proportion of water and hot water soluble substances in the rhizome. These substances seem to be certain aldehydes, carboxylic acids and carbohydrates. Next yield is in ethanol. Besides certain aldehydic compounds and certain steroids and carbohydrates, the ethanol extract contains the flavonoids also. Yield in diethyl ether is slightly less than that in alcohol. However, a comparatively high saponification value indicates the presence of more of low molecular weight compounds. No carbohydrates and flavonoids are present.

\section{References}

Abeywickrama K, AdhikariAACK, Paranagama P and Ganage CSP, 2006, The efiicacy of essential oil of Alpiniacalcarata (Rosc.) and its major constituent, 1,8cineole, as protectants of cowpea against Callosobruchusmaculatus (F.) (Coleptera: bruchidae), Canad J Plant Sc, 86(3): 821-827.

Garratt DC, 1964, Vol. III, The Quantitative Analysis of Drugs, Chapman Hall International, London.

Guenther E, 1963, The Essential Oils,Vol. II., D. Van Nostrand Company, U. S. A.

I S: 548, 1984, Indian Standards Institution, Part-1, New Delhi. Pullaiah T, 2006, Encyclopedia of World Medicinal Plants, Regency Publications, Vol. 1., New Delhi, p. 124.

Kong L, Qin M and Niwa M, 2004, Two new bislabdanicditerpenoids from Alpiniacalcarata, Acta Bot Sin, 46(2), 159-164.

The Wealth of India, 1985, A Dictionary of Indian Raw Materials \& Industrial Products, Vol.1:A, CSIR, New Delhi, p. 198. 